\title{
Vajinitlerde Etiyoloji Değişiyor mu? Tek Merkez Verilerinin Paylaşımı
}

\section{Does the Etiology Change in Vaginitis? Data Results of Samples from a Single Center}

\author{
Zehra Çağla KARAKOÇ
}

İstinye Üniversitesi Tıp Fakültesi, Enfeksiyon Hastalıkları ve Klinik Mikrobiyoloji, İstanbul

\begin{abstract}
$\overline{\mathbf{O z}}$
Vajinitler jinekoloji polikliniklerinde en sik karşılaşılan tanılardan biri olup, çoğunlukla enfeksiyöz kaynaklıdır. Çalışmamızda; jinekoloji polikliniklerine vajinal akıntı şikayeti ile başvuran hastalardan alınan vajinal sürüntü örneklerinin, mikrobiyolojik değerlendirme sonuçlarının ve etiyolojide rol alan mikroorganizmaların değerlendirilmesi amaçlanmıştır. Ocak-Haziran 2019 tarihleri arasında hastanemiz jinekoloji polikliniklerinde vajinit ön tanısı konulan 290 hastadan alınan 305 vajinal sürüntü örneği calıssmaya dahil edildi. Örneklerin mikroskobik inceleme ve kültür sonuçları klinik mikrobiyoloji laboratuvar kayıtlarından retrospektif olarak değerlendirildi. Vaginal sürüntü kültürleri; \%5 koyun kanlı agar, Çikolata agar, MacConcey agar, Sabouraud Dextroz agar besiyerlerine ekilerek, gram boyamaları ve direkt mikroskobik incelemeleri yapıldı. Plaklar 48-72 saat süre ile $37^{\circ} \mathrm{C}$ 'de inkübe edildi. Üreyen mikroorganizmaların identifikasyonu ve antibiyogramı için VITEK 2 Compact ${ }^{\circledR}$ (bioMeriéux, Marcy l'Etoile, Fransa) otomatize sistemi kullanıldı. Hastaların ortalama yaşı $35.1 \pm 10.3$ (18-84) olup, mikroorganizma üremesi saptanan örnek sayıs1 131 (\%42.9)'di ve bunların 84(\%64.1)'ünde Candida albicans'in etken olduğu belirlendi. Hastalar premenopozal ve postmenopozal ( $<45$ yaș ve $\geq 45$ yass) olarak gruplandırıldı. Premenopozal grupta vajinal sürüntü örneği kültüründe üreme oranı (118/131), C. albicans üreme oran1 (81/131) bakteriyel vajinoz ile ilişkili bulgular (25/262) daha fazla oranda belirlendi. Mikroskopik incelemede Trichomonas vaginalis saptanan hastaların tamamı premenopozal gruptaydı. Buna mukabil postmenopozal grupta ise, bakteriyel üreme oranı (10/13) daha fazlaydı. İzole edilen gram-pozitif bakterilerde ampisilin, penisilin ve gentamisin direnci saptanmadi. Gram-negatif bakterilerde ise karbapenemler ve gentamisine karș1 direnç saptanmazken, diğer antibiyotiklere olan duyarlılık \%47.2-97.2 arasında değişti. Çalışmamızda tüm hasta popülasyonu

Abstract

Vaginitis is one of the most common diagnoses in gynecology outpatient clinics and is mostly of infectious origin. The aim of this study was to evaluate microbiological results and microorganisms involved in etiology of the patients admitted to gynecology polyclinics with complaints of vaginal discharge. Between JanuaryJune 2019, a total of 305 vaginal swab samples taken from 290 patients who were admitted to gynecology outpatient clinics with vaginal discharge complaints were included in the study. Microscopic examination and culture results of the samples were retrospectively evaluated from clinical microbiology laboratory records. Vaginal swab cultures were cultivated on 5\% sheep blood agar, Chocolate agar, MacConcey agar, Sabouraud Dextroz agar media, and gram staining and direct microscopic examinations were performed. Plates were incubated at $37^{\circ} \mathrm{C}$ for $48-72$ hours. VITEK2Compact ${ }^{\circledR}$ (bioMeriéux, Marcy l'Etoile, France) automated system was used for identification and antibiogram of growing microorganisms. The mean age of the patients was $35.1 \pm 10.3$ (18$84)$, the number of cultures with microorganism growth was 131 $(42.9 \%)$, and $84(64.1 \%)$ of them were Candida albicans. The patients included in the study were grouped as premenopausal and postmenopausal $(<45$ and $\geq 45$ years $)$. In the premenopausal group, while microorganism growth rate was $118 / 131$, C.albicans growth rate was $81 / 131$, and findings related to bacterial vaginosis $(25 / 262)$ were determined to be higher. In contrast, in the postmenopausal group, bacterial growth rate (10/13) was higher. In all gram-negative bacteria, no resistance to carbapenems and gentamycin were detected, while sensitivity to other antibiotics varied between 47.2$97.2 \%$. In our study, C.albicans is the leading isolated organism among all patients. However, in the group defined as postmenopausal, bacterial agents were isolated at the highest proportion and in the premenopausal group; Candida was found to be the more common cause of vaginitis that is in consistent with the literature.
\end{abstract} değerlendirildiğinde izole edilen en sık etken $C$. albicans'tır. Ancak postmenopozal grupta bakteriyel etkenlerin ön plana geçtiği, premenopozal grupta ise; literatürle uyumlu olarak Candida'ların daha sık vajinit etkeni olduğu belirlenmiștir.

Anahtar Kelimeler: Candida, Postmenopoz, Premenopoz, Vajinit

\section{Giriş}

Cinsel aktif kadınlarda vajinal akıntı en sık rastlanan jinekolojik yakınmalardan biridir. $\mathrm{Bu}$ akıntının; renk, koku, miktar ve kıvamında gelişen değişiklikler çoğunlukla enfeksiyoz kaynaklıdır. Bu

$\begin{array}{ll}\text { Zehra Çağla KARAKOÇ } & \text { ORCID No } \\ & \text { 0000-0002-1618-740X }\end{array}$

Başvuru Tarihi / Received: $\quad$ 14.07.2020

Kabul Tarihi / Accepted : $\quad 06.08 .2020$

Adres / Correspondence : Zehra Çă̆la KARAKOC

İstinye Üniversitesi Tıp Fakültesi, Enfeksiyon Hastalıkları ve Klinik Mikrobiyoloji, İstanbul

e-posta / e-mail ckarakoc@gmail.com
Keywords: Candida, Postmenopause, Premenopause, Vaginitis

duruma neden olan hastalıklar arasında en sik rastlananlar; bakteriyel vajinoz, vulvovajinal kandidiyaz, trikomoniyazdır. Ayrıca vajinitler; inflamatuar ve hormonal (östrojen azalması) nedenlerle de gelişebilir $(1,2)$.

Bakteriyel vajinozun doğurganlık çă̆ındaki kadınlardaki görülme sıklığı \%11-48'dir. Burada; normal vajen florasında baskın olarak bulunan laktobasillerin yerini Gardnerella vaginalis, Mycoplasma spp., Mobilincus spp. ve Prevotella spp. gibi anaerop bakteriler almıştır (2). Vulvovaginal kandidiyaz ise, vajinitlerin yaklaşık 1/3'ünü oluşturmaktadır. Kadınların \% 75'i hayatları boyunca en az bir defa Candida vajiniti geçirmektedir ve etken çoğu olguda Candida 
albicans'tır (2,3). Aerobik vajinit ise; mikrobiyolojik olarak; vajen florasının gram pozitif koklar (Streptococcus agalactiae, stafilokok ve enterokok ) ve gram-negatif çomaklar (Eschericia coli, Klebsiella spp.) gibi enterik bakterilerle kolonize olması ve laktobasillerin predominansının azalması olarak tanımlanabilir (4). Trikomoniyaz; Trichomonas vaginalis'in etken olduğu, çoğunlukla cinsel yolla bulaşan ve görülme sıklığı cinsel aktivite ile artan önemli bir protozoondur. Çoğu vaka asemptomatik seyretmektedir. Günümüzde; nükleik asit amplifikasyon testlerini içeren hızlı tanı kitleri, direkt mikroskobik incelemeden 3-5 kat daha duyarlıdır (2).

Vajinal enfeksiyonlar, tedavi edilmedikleri zaman pelvik inflamatuar hastalığa neden olabilir. $\mathrm{Bu}$ durum; infertilite, ektopik gebelik, preterm doğum ve düşük doğum ağırlıklı bebek, koryoamnionit gibi komplikasyonlara neden olabilir. Ayrica bu enfeksiyonlar; Herpes Simplex Virus (HSV) ve Human Immunodeficiency Virus (HIV) gibi enfeksiyonların cinsel yolla geçişini de artırabilirler. $\mathrm{Bu}$ nedenle; vajinitlerin tanısı ve tedavisinde, etiyolojide rol alan mikroorganizmaların belirlenmesi önemlidir (5).

Çalışmamızda; jinekoloji polikliniklerine vajinal akıntı şikayeti ile başvuran hastalardan alınan vajinal sürüntü örneklerinin, mikrobiyolojik değerlendirme sonuçlarının ve etiyolojide rol alan mikroorganizmaların retrospektif olarak değerlendirilmesi amaçlanmıştır.

\section{Gereç ve Yöntem}

Ocak-Haziran 2019 tarihleri arasında hastanemiz jinekoloji polikliniklerine vajinal akıntı şikayeti ile başvuran ve vajinit ön tanısı konulan $\geq 18$ yaş, jinekolojik malignitesi ve immunosüpresif hastalığı ve diyabeti olmayan toplam 290 hasta çalışmaya dahil edildi. Bu hastalardan alınan vajinal sürüntü örneğinin (toplam 290 hastadan 305 örnek), mikrobiyolojik inceleme ve kültür sonuçları klinik mikrobiyoloji laboratuvar kayitlarından retrospektif olarak değerlendirildi. Steril jelli eküvyon çubuğu (Hema-Lab, Türkiye) ile alınan vaginal sürüntü kültürleri; \%5 koyun kanlı agar, Çikolata agar, Mac Concey agar, Sabouraud Dextroz agar besiyerlerine ekilerek, gram boyamaları ve direkt mikroskobik incelmeleri yapıldı. Plaklar $48-72$ saat süre ile $37^{\circ} \mathrm{C}$ de inkübe edildi. Üreyen mikroorganizmaların identifikasyonu ve antibiyogramı için VITEK 2 Compact ${ }^{\circledR}$ (bioMeriéux, Marcy l'Etoile, Fransa) otomatize sistemi kullanıldı. T. vaginalis enfeksiyonu tanıs1, taze preparatta direkt mikroskobik incelemede parazitin görülmesi ile kondu. Gram boyama; lökosit, vajina epitel hücreleri, clue hücreleri (vajina epitel hücrelerinin gram değişken kokobasillerle kaplanması), mobilincus benzeri gram-negatif kıvrık çomaklar, maya ve farklı bakteriyel morfolojiler açısından değerlendirilerek raporlandı. Gram boyamada; laktobasillerin predominant olması ve lökosit-epitel hücreleri oranının biri geçmemesi "normal" olarak değerlendirildi. Veriler istatistiksel analiz için SPSS (Statistical Package for Social Sciences) Windows 11.0 software'e kaydedilerek analiz edildi. Verilerin istatistiksel değerlendirmesinde; aynı hastadan farklı zamanlarda alınan her bir vajinal sürüntü örneği tek bir hasta olarak belirlendi.

\section{Bulgular}

Hastaların ortalama yaşı $35.1 \pm 10.3$ (18-84) olup, mikroorganizma üremesi saptanan örnek sayısı 131 (\%42.9) idi. Çalışmaya alınan 305 vajinal sürüntü örneğinin mikrobiyolojik değerlendirme sonucu, izole edilen mikroorganizmaların dağılımı, yaş grupları arasında karşılaştırmaları ve gram-negatif bakterilerin çeşitli antibiyotiklere olan duyarlılıkları Şekil 1,2 ve Tablo 1,2'de verildi. Vajinal sürüntü örneklerinin beşinde iki farklı mikroorganizma üremesi saptand1. Bunların üçünde ortak üreyen etken Candida albicans olup, her bir olguya sirası ile Enterococcus faecalis, E. coli, S. agalactiae eşlik etmekteydi. Diğer iki örnekte ise ortak üreyen etken E. faecalis'ti ve buna E. coli veya Klebsiella pneumoniae eşlik etmekteydi. Üreme olan 131 örneğin; 84 (\%64.1)'ünde C. albicans'ın etken olduğu belirlendi. Candida izolasyonu yapılan hastaların yaş aralığı; 20-53 yaş arasında değişmekteydi. Oysaki, bakteri izole edilen hastaların oranı 131 üremeli örnek içinde 47 (\%35.8) olup, yaş dağılımı daha geniş bir aralıkta (19-81 yaş) idi. İzole edilen; iki $E$. coli ve iki $K$. pneumoniae'de genişlemiş spektrumlu beta laktamaz aktivitesi belirlendi. Çalışmaya dahil edilen hastalar premenopozal ve postmenopozal $(<45$ yaş ve $\geq 45$ yaş) olarak gruplandırıldı (Tablo 1). Premenopozal grupta vajinal sürüntü örneği kültüründe üreme oranı 118/13 (\%90), C. albicans üreme oran1 81/131 (\%61.8) bakteriyel vajinoz ile ilişkili bulgular 25/262 (\%9.5) daha fazla oranda belirlendi. Mikroskopik incelmede $T$. vaginalis saptanan hastaların tamamı da premenopozal grupta idi. Buna mukabil postmenopozal grupta ise, bakteriyel üreme oranı 10/13 (\%76.9) daha fazlaydı. İzole edilen gram-pozitif bakterilerde (S. agalactiae, E. faecalis) ampisilin, penisilin ve gentamisin direnci saptanmadi. Tüm gram-negatif bakterilerde ise karbapenemler ve gentamisine karşı direnç saptanmazken, diğer antibiyotiklere olan duyarlılık \%47.2-97.2 arasında değişti (Tablo 2).

\section{Tartışma}

Vajinitlerde; çoğunlukla başvuru şikayeti etiyolojiden bağımsız olarak vajinal akıntı, kaşıntı ve yanmadır. Bu nedenle etkenin belirlenmesi başarılı tedavide en önemli basamaklardan biridir (6). Çalışmamızda vajinit ön tanısı ile gönderilen toplam 
305 vajinal sürüntü örneğinin 131'inde mikroorganizma üremesi saptanmış olup; bunların 84'ü C. albicans (\%27.5), 47'sini (\%15.4) ise enterik gram-negatifler ve gram-pozitif bakteriler oluşturmaktadır. Mikroskopide bakteriyel vajinoz ile ilgili bulgular 26 örnekte $(\% 8.5)$ ve $T$. vaginalis ise altı örnekte (\%2) belirlenmiştir. Kültür örneklerinin 96'sında (\%32) ise mikroskobik inceleme ve kültürde patoloji saptanmamıştır.

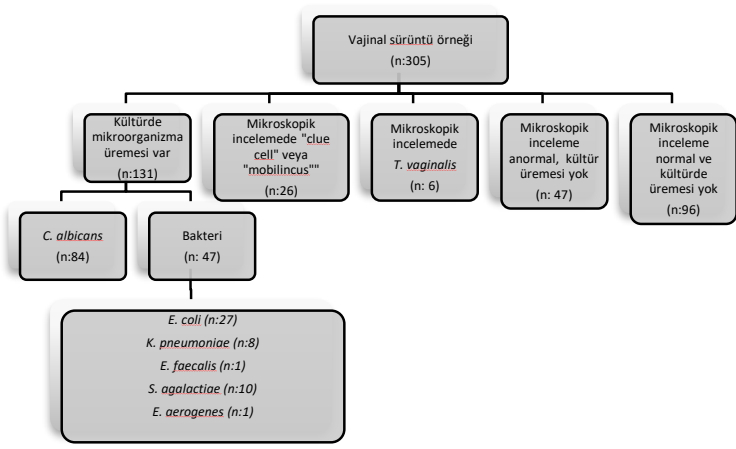

Şekil 1. Vajinal sürüntü örneklerinin mikrobiyolojik değerlendirme sonuçları

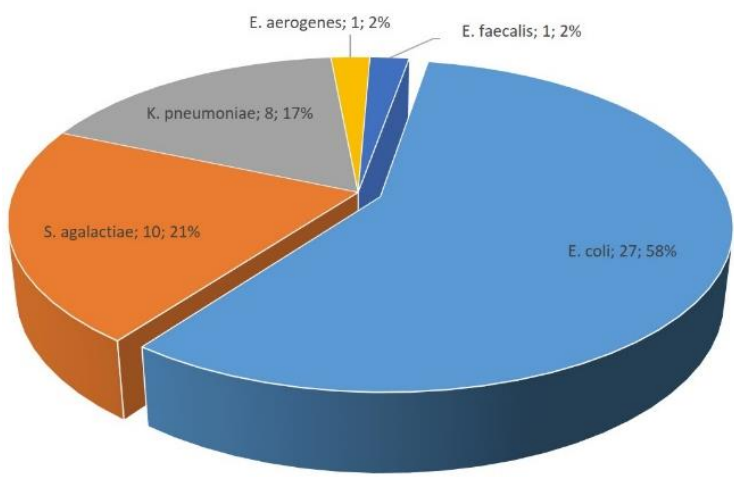

Şekil 2. Üreyen bakterilerin tür dağılımı

Tablo 1. Vajinal sürüntü örneklerinin mikroskopik inceleme ve kültür üreme sonuçlarının yaş grupları arasında karşılaştırılması

\begin{tabular}{lcc}
\hline & $<\mathbf{4 5}$ yaş $(\mathbf{n} / \mathbf{N})$ & $\mathbf{2 4 5}$ yaş $(\mathbf{n} / \mathbf{N})$ \\
\hline Örnek sayıs1 & 262 & 43 \\
Kültürde üreme olması & $118 / 131(\% 90)$ & $13 / 131(\% 10)$ \\
$C$. albicans & $81 / 118(\% 67)$ & $3 / 13(\% 23)$ \\
Bakteri üremesi & $37 / 118(\% 31)$ & $10 / 13(\% 77)$ \\
$T$. vaginalis & $6 / 262(\% 2)$ & - \\
Gram boyamada "clue & & $1 / 43(\% 2)$ \\
cell" & $25 / 262(\% 10)$ & \\
veya mobilincus & & \\
görülmesi & & \\
\hline
\end{tabular}

Tablo 2. İzole edilen gram negatif bakterilerin çeşitli antibiyotiklere olan duyarlılık yüzdeleri

\begin{tabular}{lc}
\hline Antibiyotikler & Duyarlılık yüzdesi \\
\hline Ampisilin & $\% 47.2$ \\
Ampisilin-sulbaktam & $\% 58.3$ \\
Seftriakson & $\% 91.7$ \\
Piperasilin-tazobaktam & $\% 97.2$ \\
Imipenem & $\% 100$ \\
Gentamisin & $\% 100$ \\
Siprofloksasin & $\% 91.7$ \\
Trimetoprim-sulfametaksazol & $\% 86.1$ \\
\hline
\end{tabular}

Bakteriyel vajinozun prevalansı dünyada \%4.558.3 arasındadır (7). Bu durumun çalışmaya dahil edilen popülasyonun özellikleri (yüksek prevelansın; düşük sosyoekonomik düzey, kötü hijyen koşulları, malnütrisyon) ve tanı yöntemleri ile ilgili olduğu düşünülmektedir. Vajinal sürüntü kültürü çoğu bakteriyel enfeksiyonun tanısında kullanılan altın standart bir yöntemdir. Ancak bakteriyel vajinozda, mikroorganizmanın üretilmesi zor olduğundan kültür altın standart bir yöntem olarak kullanılmamaktadır. Literatürde $G$. vaginalis' in kültürde üretilme oranı $\% 6-10$ arasında değişmektedir (8). Gram boyama ise; ucuz, kısa süreli ve hemen her yerde kolaylıkla ulaşılabilen bir laboratuvar yöntemidir. Çalışmalarda gram boyamada bakteriyel vajinoz tanıs1 koyma duyarlılığı \%89-93 ve özgüllüğü ise \%70-83 arasında değişmektedir (9). Ayrıca, bakteriyel vajinoz tanısında Amsel kriterleri ile tanı da genel olarak kabul gören bir yöntemdir. Burada ince ve homojen akıntı olması, Whiff testinin pozitifliği, mikroskobik incelemede clue cell görülmesi ve vajinal pH'nın 4.5 büyük olması değerlendirilen kriterlerdir. Gram boyama ile kıyaslandığında bu kriterlerden en az üçünün pozitif olması \%70-90 duyarlılık ve \%90-94 özgüllükle tanı koydurmaktadır. Tanıda kullanılan diğer bir yöntem ise Nugent skorlamasıdır ve bu yöntem bakteriyel vajinozda altın standart kabul edilen bir yöntemdir. Ancak tecrübe istemesi ve zaman alıcı olması nedeniyle çoğu zaman çalışma amaçlı olarak kullanılmaktadır (10). Çalışmamızda bakteriyel vajinoz ile ilgili bulgular gram boyama ile değerlendirilmiş olup, bakterinin standart besiyerlerinde identifikasyonun zor, zaman alıcı ve maliyetli olması nedeni ile kültüre dayalı değerlendirme yapılmamıştır.

Candida vajiniti bakteriyel vajinozdan sonra ikinci sıklıkla rastlanan vajinal enfeksiyon etkenidir. Doğurganlık çağındaki kadınların \%75 yakını hayatları boyunca en az bir defa vulvovajinal kandidiyaz geçirmekte ve bunların da yarısında enfeksiyon tekrarlamaktadır. Dünyada vajinal kolonizasyon \%17-30 arasında rastlanmakta olup, kadın hayatının dönemleri boyunca değişkenlik göstermektedir. Puberte öncesi ve menopoz sonrası dönemde östrojen azlığına bağlı vajinal kolonizasyon daha az orandadır. Vajinal Candida kolonizasyonu veya enfeksiyonu pek çok faktöre bağlıdır. Bunlar; konağa bağlı faktörler (östrojenik aktivite, antibiyotik kullanımı, diyabet ve immun süpresyon..), mikrobiyal faktörler (gonokok veya B grup streptokok enfeksiyonu geçirmek..), davranış ile ilgili faktörler ( cinsel aktivitenin sıklığ kullanımı vb.), genetik ve diğer faktörler olarak sınıflanabilir. Candida türleri içinde de vajinal enfeksiyonlarda en sik (\%98) izole edilen $C$. albicans olup, diğer Candida türleri sıklıkla immunosüpresif, diyabetik ve postmenopozal kadınlarda görülmektedir $\quad(5,11)$. Ülkemizden 
yapılan çalışmalarda; vajinal sürüntü kültürlerinde Candida üreme oranı \%16-39.8 arasinda bulunmuştur (12-14). Çalışmamızda vajinal kültürlere $C$. albicans üreme oranı \%27.5 saptanmış olup bunların da büyük çoğunluğu (\%94.6) 45 yaş altı kadınlar olarak belirlenmiştir. $\mathrm{Bu}$ durum yukarıda da belirtildiği gibi bu grupta östrojenik aktivitenin (doğurganlık çağı ve gebelik) ve cinsel aktivite sıklığının daha fazla olması ile açıklanabilir.

Vajinal mikrobiyotada çok sayıda farklı mikroorganizma bir denge içinde bulunmaktadır. $\mathrm{Bu}$ dengeyi sağlayan en önemli faktör ise aerobik vajinal mikrobiyotanın \%90'a yakın kısmını oluşturan laktobasillerdir. Laktobasillerin yanında vajende; $C$. albicans, S. aureus, S. agalactiae gibi kommensal mikroorganizmalar da yaşamaktadır (15). Aerobik vajinit; vajende laktobasil predominasının azalması ve bakteriyel vajinoza göre çok daha fazla inflamatuar değişikliklerle birlikte, aerobik enterik patojen veya kommensal bakterilerin (B grup streptokok ( $S$. agalactiae), E. faecalis, $E$. coli ve Staphylococcus aureus) bulunmasidir. Aerobik vajinit gebelerde \%8-11 oranında saptanırken, vajinal akıntı şikayeti olan kadınlarda \%5-24 oranında saptanabilmektedir $(15,16)$. Bir çalışmada; 610 vajinal sürüntü kültüründe üreyen aerobik bakteriler değerlendirildiğinde s1klık sirasina göre; E. coli $(24.92 \%)$, K. pneumoniae (23.5\%), S. aureus (16.52\%), Enterococcus spp. $(8.40 \%)$ ve koagülaz negatif stafilokok $(6.44 \%)$ olarak izole edilmiştir. Gebe olmayanlar ve 25-40 yaş aralığında ise bu bakterilerin üreme oranı daha yüksek oranda saptanmıştır (17). Literatürde izole edilen gram-negatif bakteriler içinde ise; önde gelen etkenin \%69.3-76 s1klıkla E. coli olduğu bildirilmiştir $(12,13,18)$. Çalışmamızda vajinal sürüntülerde aerobik enterik patojen üreme oranı 47/305 (\%15.4) olarak belirlenmiştir. İzole edilen gram-negatif çomaklar büyük çoğunluğunu ise $E$. coli 27/36 (\%75) oluşturmuştur. Ayrıca yine literatürle uyumlu olarak bu patojenler premenopozal grupta daha yüksek oranda 37/47 (\%78.7) saptanmıştır.

Grup B streptokoklardan olan Streptococcus agalactia; normalde insanda barsak ve genitoüriner sisteminde bulunmaktadır. Sağlıklı kişilerde \%4-18 arasında kolonizasyon saptanabilmektedir. Sağlıklı insanda nadiren enfeksiyonlara neden olan bu bakteri; yaşl1, gebe ve komorbiditesi olan hastalarda önemli bir morbidite nedenidir. Son yıllarda gebe olmayanlarda da insidansının arttığ bildirilmektedir (19). Gebelerde vajinal kolonizasyonu; yenidoğanda menenjit, sepsis, pnömoni gibi önemli komplikasyonlara neden olabilmektedir (15). Ayrıca Grup B streptokok taşıyıcılığının intermittan olduğu, menstrüel faza göre değiştiği ve selektif besiyeri ile izole edilme oranın arttığı göz ardı edilmemesi gereken durumlar arasinda yer almaktadır (20). Çalışmamızda grup B streptokoklar
10/310 (\%3.2) saptanmış olup, çoğunluğu ise 45 yaş altındadır.

Trikomoniyaz ise vajinit etkenleri arasında yer alan ve cinsel yol ile bulaşan, direkt mikroskopik incelemede hareketli, kamçılı parazitin görülmesi ile tanınan bir protozoondur. Ancak hemen her laboratuvarda kullanılan bu inceleme yöntemi, hızlı ve ucuz olmasına rağmen duyarlılığı düşüktür (21). $\mathrm{Bu}$ nedenle günümüzde daha yüksek duyarlılıklar sahip olan hizlı amplifikasyon testleri önerilmektedir. Ancak bu testlerin de yaygın kullanımı maliyet etkinliği nedenli ile sınırlıdır. Literatürde \%2.1-8.5 arasında olan $T$. vaginalis sıklığı ülkemizden yapılan çalışmalarda da \%2.6-7 arasinda bildirilmektedir (12,22-25). Bizim çalışmamızda $T$. vaginalis görülme sıklığı ise literatürle uyumlu olarak $\% 2$ oranında saptanmış olup olguların tamamı cinsel aktif dönemde olan kadınlardır. Çalışmamızın kısıtlıyıcı yönleri ise; olgu sayısının azlığı, bakteriyel vajinoz tanısında Amsel kriterleri veya Nugent skorlamasının kullanılmaması ve retrospektif bir çalışma olmasıdır. Sonuç olarak; akut vajinitler her yaş grubunda jinekoloji polikliniklerine olan başvuruların önemli bir bölümünü oluşturmaktadır. Etkin tedavinin uygulanmadığı durumlarda pelvik inflamatuar hastalık, infertilite ve gebede geliştiğinde ise yenidoğanda menenjit veya sepsis gibi ciddi komplikasyonlara yol açabilen bir durumdur. Tüm bu gerekçelerle de önemli bir toplum sağlığı sorunu olmaya devam etmektedir. Doğru tedavi için etiyolojide yer alan mikroorganizmaların hızlı ve doğru olarak belirlenmesi önemlidir. Çalışmamızda tüm hasta popülasyonu değerlendirildiğinde izole ettiğimiz en s1k etken $C$. albicans'tır. Ancak postmenopozal ( $\geq 45$ yaş) olarak tanımladığımız grupta bakteriyel etkenlerin ön plana geçtiği, premenopozal grupta ise literatürle uyumlu olarak Candida'lar daha sik vajinit etkeni olarak belirlenmiştir. Verilemiz tek merkezin sonuçlarını yansıtmakta olup, olgu sayımızdaki kısıtlılık nedeni ile konu ile ilgili kapsamlı çalışmalar ile desteklenmesi uygun olacaktır.

Etik Kurul Onayı: İstinye Üniversitesi Liv Hastanesi Etik Kurulu'ndan 13.07.2020 tarih ve 2020/26 kayıt numarası ile etik kurul onayı alınmıştır.

\section{Kaynaklar}

1. Mccormack WM. Vulvovaginitis and cervicitis. In: Mandell GL, Bennett JE, Dolin R, editors. Mandell, Douglas, and Bennett's Principles and Practice of Infectious Diseases. 7th ed. Philadelphia, PA: Churchill Livingstone Elsevier; 2010. pp 1495-1509.

2. Sobel JD. Vaginitis, vulvitis, cervicitis and cutaneous vulvar lesions. In: Cohen J, Powderly WG, Opal SW editors. Infectious Diseases. 3rd edition. Edinburgh: Elsevier Limited; 2010. pp. 542-50.

3. Workowski KA, Bolan GA. Centers for Disease Control and Prevention. Sexually transmitted diseases treatment 
guidelines, 2015. MMWR Recomm Rep. 2015;64(RR-03):1137.

4. Tempera G, Furneri PM. Management of aerobic vaginitis. Gynecol Obstet Invest. 2010;70(4):244-9.

5. Mills BB. Vaginitis: Beyond the basics. Obstet Gynecol Clin North Am. 2017;44(2):159-77.

6. Goje O, Munoz JL. Vulvovaginitis: Find the cause to treat it. Cleve Clin J Med. 2017;84(3):215-24.

7. Kenyon C, Colebunders R, Crucitti T. The global epidemiology of bacterial vaginosis: a systematic review Am J Obstet Gynecol. 2013;209(6):505-23.

8. Baruah FK, Sharma A, Das C, et al. Role of Gardnerella vaginalis as an etiological agent of bacterial vaginosis. Iran J Microbiol. 2014;6(6):409-14.

9. Chandeying V, Skov S, Kemapunmanus M, et al. Evaluation of two clinical protocols for the management of women with vaginal discharge in Southern Thailand. Sex Transm Infect. 1998;74(3):194-201.

10. Bansal R, Garg P, Garg A. Comparison of Amsel's criteria and Nugent's criteria for diagnosis of bacterial vaginosis in tertiary care centre. Int J Reprod Contracept Obstet Gynecol. 2019;8:637-40

11. Chatzivasileiou P, Vyzantiadis TA. Vaginal yeast colonisation: From a potential harmless condition to clinical implications and management approaches-A literature review. Mycoses. 2019;62(8):638-50.

12. Kalkancı A, Çiftçi B, Biri A, et al. Vajinit ön tanısı almış olgularda vajinal kültür sonuçlarının değerlendirilmesi. Türkiye Klinikleri J Gynecol Obst. 2005;15:137-9.

13. Cengiz A, Cengiz L, Us E. Gebe kadınların vajinal akıntılarından üretilen mikroorganizmaların dağılımı ve antibakteriyellere duyarlılıkları. OMÜ Tıp Derg. 2004;21(2):84-9.

14. Esim BE, Kars B, Karsidag AY, et al. Diagnosis of vulvovaginitis: comparison of clinical and microbiological diagnosis. Arch Gynecol Obstet. 2010;282(5):515-9.

15. Kaambo E, Africa C, Chambuso R, et al. Vaginal microbiomes associated with aerobic vaginitis and bacterial vaginosis. Front Public Health. 2018;6:78.
16. Sangeetha KT, Golia S, Vasudha CL. A study of aerobic bacterial pathogens associated with vaginitis in reproductive age group women (15-45 years) and their sensitivity pattern. Int J Res Med Sci. 2015;3:2268-73.

17. Pal K, Sidhu SK, Devi P, et al. Etiology of vaginal infections and antimicrobial resistance pattern of aerobic bacterial isolates in women of reproductive age group attending a tertiary care hospital. Asian Pac J Health Sci. 2017;4(4):15-

18. Hussain MS, Hussain A, Azam M, et al. Frequency and antimicrobial susceptibility of gram negative rods in high vaginal swabs. JSZMC. 2014;5(2):612-4.

19. Raabe VN, Shane AL. Group B Streptococcus (Streptococcus agalactiae). Microbiol Spectr. 2019;7(2).

20. Shaw C, Mason M, Scoular A. Group B streptococcus carriage and vulvovaginal symptoms: causal or casual? A case-control study in a GUM clinic population. Sex Transm Infect. 2003;79:246-8

21. Van Gerwen OT, Muzny CA. Recent advances in the epidemiology, diagnosis, and management of Trichomonas vaginalis infection. F1000Res. 2019;8(F1000 Faculty Rev):1666.

22. Madhivanan P, Bartman MT, Pasutti L, et al.. Prevalence of Trichomonas vaginalis infection among young reproductive age women in India: implications for treatment and prevention. Sex Health. 2009;6(4):339-44.

23. Mulu W, Yimer M, Zenebe Y, et al. Common causes of vaginal infections and antibiotic susceptibility of aerobic bacterial isolates in women of reproductive age attending at Flegehiwot Referral Hospital, Ethiopia: a cross sectional study. BMC Womens Health. 2015;15:42.

24. Sönmez C, Usluca S. Ürogenital akıntısı olan olgularda: Trichomonas vaginalis sıklığı? FLORA. 2018;23(2):79-83.

25. Akarsu GA. Investigation of Trichomonas vaginalis in patients with nonspecific vaginal discharge. Turkiye Parazitol Derg. 2006;30(1):19-21. 